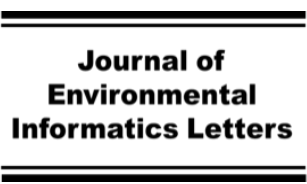

www.iseis.org/jeil

\title{
Evaluation of Water Management Effectiveness by a Multi-Dimensional Approach
}

\author{
G. W. Huang*, Y. Wei, and F. Kuan \\ Graduate School of Global Environmental Studies, Sophia University, Chiyoda Ward, Tokyo 102-8554, Japan
}

Received 3 March 2020; revised 13 March 2020; accepted 22 March 2020; published online 31 March 2020

\begin{abstract}
As water is utilized in various ways across the whole spectrum of human life, better understanding of water management effectiveness and sharing of information and experience are crucial for achieving sustainability from a water perspective. However, water management effectiveness in the long term has been insufficiently studied due partially to the lack of long term data and methodology for long term assessment. The present study presents a case study, dealing with the environmental restoration of a once listed as the worst lake in Japan for 27 years through a water diversion project. It highlights the need and importance of evaluating water management practice from both chemical and biological dimensions for its long-term effectiveness. By combining field surveys of phytoplankton communities and E. coli at multiple locations in the lake in different seasons and data analysis of long term change of chemical parameters of water quality, it revealed that although the diversion project led to a shift in phytoplankton community structure from being bluegreen algae dominated to diatom dominated, the eutrophic level remains high and the diatom-dominated phytoplankton community structure is probably the factor hindering the true recovery of the ecosystem in the lake. Wording differently, the diversion operation alleviated the symptom of eutrophication but did not solve the problem. A message form the present study is that such a multi-dimensional assessment approach allows the explanation of water management effectiveness in ecological relevance and identification of the direction for further improvement work. Therefore, it also serves as a call for the further development of multi-dimensional assessment approaches.
\end{abstract}

Keywords: water management, long-term assessment, water diversion, Lake Tega, phytoplankton

\section{Introduction}

Water management has been the subject of intensive studies ranging from water resources supply, flood risk analysis and reduction to water environment restoration and conservation (Biswas, 2004; Vojinovic and Abbott, 2012; Jha et al., 2012; Schmutz et al., 2014; Cosgrove et al., 2015; Rathnayaka et al., 2016; Angel-opoulos et al., 2017; Morrison et al., 2018). Poor water manage-ment has intensified urban flooding to become the most frequent natural disastrous event, taking place every year across the world. Poor water management also causes some 1.1 billion people world-wide to lack access to water, and a total of 2.7 billion people to be without water for at least one month of the year (WWF Water Scarcity). Besides, poor wastewater management is a problem for 2.4 billion people due to their exposure to diseases, such as cholera, typhoid fever, and other waterborne illnesses. As a consequence, two million people, mostly children, die each year from diarrheal diseases alone (UN-Water). On the other hand, there have been good practices in water management. For example, the city of Shenzhen is leading in the reform of local water management in China by entrusting all water-related government functions into one government agency (Chang, 2012). Zhangye City in the middle

* Corresponding author. Tel.: 81-3-3238-4667

E-mail address: huanggwx@sophia.ac.jp (G. W. Huang).

ISSN: 2663-6859 print/2663-6867 online

(C) 2020 ISEIS All rights reserved. doi:10.3808/jeil.202000028. reaches of the Heihe river basin is a successful case of rational water resources allocation (Huang, 2015). For water quality, the use of constructed wetlands has achieved great success (WWT Consulting, 2018). Nevertheless, dealing with water quantity in the context of urban flooding and addressing nonpoint source pollution and ecosystem restoration issues still lack anticipated progress despite large numbers of best management practices (BMPs) being implemented. Therefore, to promote BMPs in water management, it is important to conduct evaluations of the effectiveness of various water management practices from various view angles with consideration of time scale. So far, however, many studies have explored only the immediate or short-term water quantity and quality impacts of individual BMPs. Besides, most studies are sector-based evaluations. For example, water quality and hydrologic function of urban BMPs have been summarized in several review articles (Dietz, 2007; Berndtsson, 2010; Collins et al., 2010; Ahiablame et al., 2012; LeFevre et al., 2014; Liu et al., 2014). The studies of urban BMPs cited in these review articles are typically short-term (typically $1 \mathrm{~h}$ to 4 years) and sector-based. The performance of agricultural BMPs has also been reviewed (Walmsley and Pearce, 2010). Similar to urban studies, studies cited in these review articles are typically short-term and sector-based.

Studies of long-term assessment include the work by UusiKämppä and Jauhiainen (2010), which assessed the ability of grass buffer strips to retain phosphorus in different seasons over 17 years and found that effectiveness was decreasing with 
time and fluctuated with season. Komlos and Traver (2012) evaluated the effectiveness of rain gardens in reducing orthophosphate over a period of nine years and found no decreasing trend in orthophosphate. Overall, research works on long-term assessment of effectiveness of water management practices are limited and conducted largely in different fields without sufficient cross-sector dialogues among researchers. Therefore, further research on the long-term evaluation of the effectiveness of water management practices is needed for further development and better application of BMPs. The present paper is intended to shed some new light on the long-term effectiveness of a common water management practice through a case study. It highlights the fact that the widely used chemical assessment using conventional water quality parameters such as chemical oxygen demand (COD), $\mathrm{pH}$, dissolve oxygen (DO), electrical conductivity (EC) and nutrients alone may not be conclusive and the combination with biological assessments such as phytoplankton community structure can be effective in evaluating the longterm effect of water management.

\section{Materials and Methods}

\subsection{Study Site}

The case under consideration is Lake Tega, located in Chiba Prefecture, Japan. It is a shallow lake with a mean depth of 0.9 $\mathrm{m}$, and its surface area and volume are $6.5 \mathrm{~km}^{2}, 5.6 \times 106 \mathrm{~m}^{3}$, respectively. The area of the lake's watershed is 16,270 ha and about 485,000 people live in the watershed. Due to urbanization in the watershed and lagging behind of sewer system construction, large amounts of pollutant loadings entered the lake in the 1970s. As a result, Lake Tega became the worst lake in Japan in 1974 in terms of COD and the title of the worst lake in Japan remained for the subsequent 27 years. Currently, sewer system coverage in the watershed is more than $90 \%$. So far, the lake has been studied intensively from physical, chemical and ecological perspectives overt the past decades. For example, Motohashi (1986) studied the phosphate release from the bottom sediments, Matsunashi et al. (1999) analyzed seasonal and spatial characteristics of water quality in the lake, Tabuchi (2008) estimated nitrogen and phosphorus loadings into the Lake. Iwayama et al. (2012) reported the change in phytoplankton community structure of the lake, and Huang (2011) studied the lake from a historical perspective dating back to Edo Era. By examining land use change and estimating pollutant loadings accordingly, Huang concluded that the policy mismatch between agricultural management and dam development is the root cause of the environmental degradation of the lake.

In 1974, the Japanese land ministry launched the construction of the North Chiba water diversion project, connecting the Tone River with the Edor River for the purpose of river flow regime regulation. During the construction period, a new role was added to the project to divert an amount of water to Lake Tega to help the lake restore its ecosystem. The diversion project started its operation from 2000. The river water flows into the lake at the west part of the lake and the lake water flows out to the river at the east end forming a kind of circulation. Consequently, this diversion operation has both the function of dilution and reducing the lake's retention time.

Water quality improvement by adding dilution water has indeed been practiced for several decades across the world. The water quality of Moses Lake in Washington, U.S. was improved by adding dilution water into it (Welch and Patmont, 1980). Baiyangdian Lake in China, as an important freshwater wetland, has been given inter-basin water transfer from the Yuecheng Reservoir and the Yellow River to maintain minimum environmental flows (Yang and Yang, 2014). Lake Taihu has also accepted water from the Yangtze River to improve the lake water quality (Hu et al., 2010). The current study was aimed at assessing the effectiveness of the North Chiba water diversion project over a long period of time from 2000 to 2019.

\subsection{Methods}

Water quality in natural water bodies depends on various factors ranging from meteorological condition to land use in its watershed. Therefore, water quality should be assessed from various angles in order to develop a better understanding of water quality dynamics for proper water management. However, chemical parameters of water quality are most widely used to detect trend of change. Since chemical data are instantaneous in nature, varying with time and space, they represent only a "snapshot" of the current conditions in aquatic systems, giving only a transient picture of prevailing environmental trends. In the case that chemical parameters of water quality vary significantly less than the sampling interval, it will require long time series to detect any change. Furthermore, it can be difficult to explain the ecological relevance of detected variability in chemical parameters of water quality since our understanding of relationships between habitat conditions and biological communities remains poor.

Whereas biological aspects of water bodies such as fish and phytoplankton communities are relatively stable and indeed can be considered as the long-term consequence of physical and chemical conditions. If physical conditions of a water body are stable, then the biological status can be viewed as the reflection of chemical conditions. Thus, better water management can be achieved through proper interpretation of water quality parameters in relation to biological conditions. Following this line of reasoning, the present study investigated the target water body using both conventional chemical parameters and microorganism communities.

On-site water sampling for in-lab analysis of phytoplankton communities was conducted at locations upstream and downstream of the diversion channel inlet in different seasons from 2017 to 2019 as shown in Figure 1.

For phytoplankton sampling, $15 \mathrm{~mL}$ of Lugol's Solution was added to every $1 \mathrm{~L}$ of sample water for sample preservation. Samples were then stored in the dark under refrigeration $(5$ $10^{\circ} \mathrm{C}$ ) for a minimum of 48 hours.

For phytoplankton identification, a Leica DM 750 Microscope was used for the identification and enumeration of phytoplankton species. Identification of phytoplankton species was based on morphological and other visible criteria with referenc- 


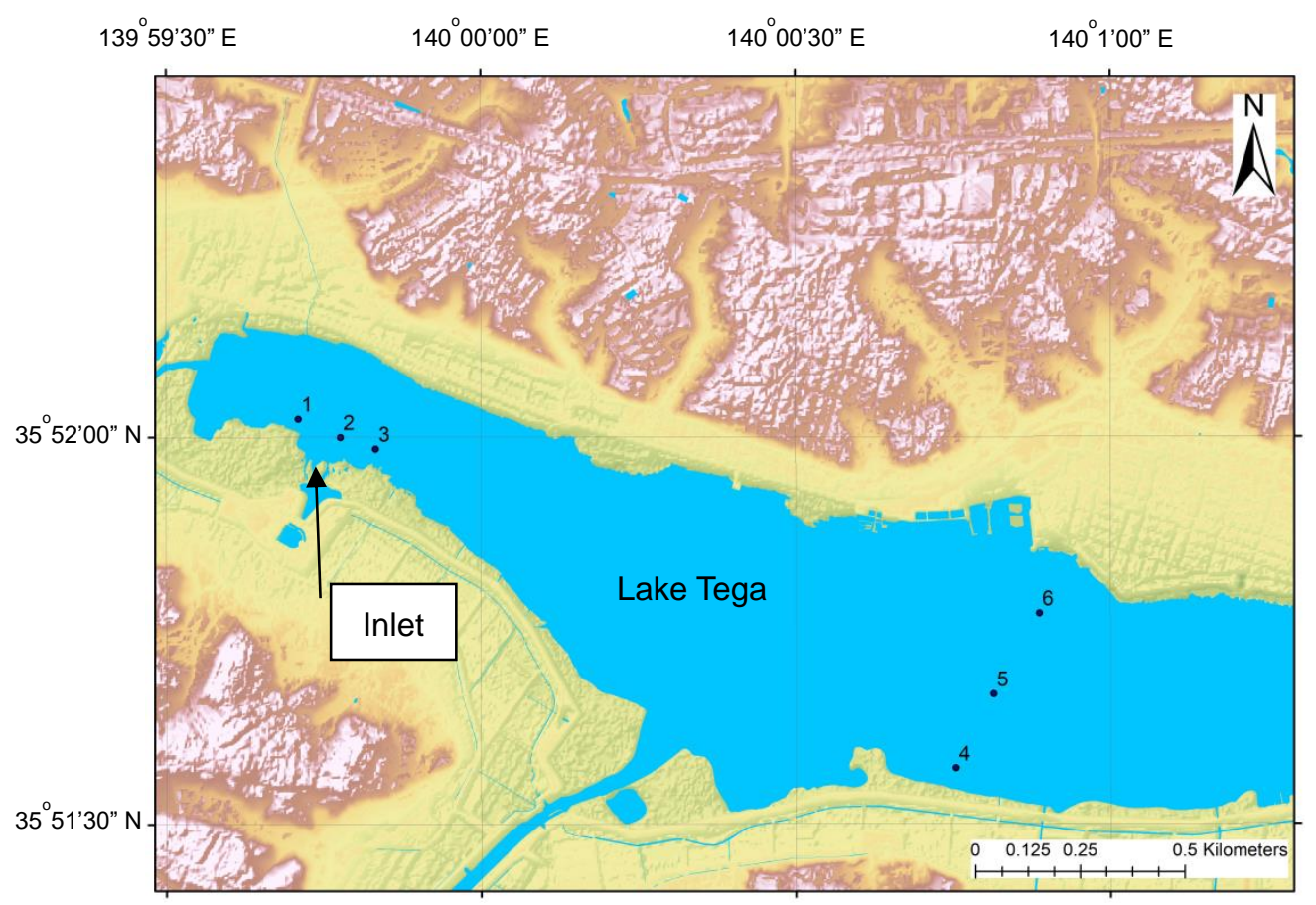

Figure 1. Sampling locations.

ing to key literature and websites for phytoplankton identification. A plankton chamber with 400 grid boxes with a length of $0.5 \mathrm{~mm}$ was used for cell counting. The 10 times eyepiece and 20 times objective lens were used, allowing images with 200 times magnification to be obtained so that phytoplankton could be clearly observed and counted. Environmental data of the lake available in the public domain were also used for characterizing the long-term change of the lake.

In addition to phytoplankton analysis, water samples were also analyzed for E. coli detection and phytoplankton composition identification. E. coli detection was conducted using MicroSnap $^{\mathrm{TM}} E$. coli test kits, which utilize a rapid bioluminogenic method for the detection and enumeration of E. coli bacteria. Samples taken from the survey sites were incubated in growth media for 6 hours, following which the detection device was activated and samples were further incubated for 10 minutes. At this time, a specific substrate reacts with diagnostic enzymes to produce light. The light generating signal is then quantified in the EnSURE luminometer.

For chemical assessment, long-term data of water quality parameters were collected from Chiba Prefectural Government and Water Information System, Ministry of Land, Infrastructure, Transport and Tourism, Japan. They include COD, total phosphorus (TP), total nitrogen (TN) and Secchi disk (SD) depth.

For trend analysis, change point analysis was employed, which uses a combination of cumulative sum charts (CUSUM) and bootstrapping, to detect the points of change over a long period of time (Bandurek, 2008). For implementation, the technique of Taylor (2000) was employed to detect mean-shifts in data.
For assessment using phytoplankton information, spatial and temporal variations of species composition were examined and phytoplankton diversity indices were used to characterize the change in species composition induced by the diversion project.

\section{Results and Analysis}

Figures 2 and 3 show the long-term change of COD, TP and $\mathrm{TN}$ in the lake, respectively. It can be seen from Fig. 2 that COD had been decreasing since 1995 so that the effect of the diversion project is not visibly apparent. For further analysis, three-year moving averages of COD data from 1969 to 2028 were taken, and examined with change-point analysis. The analysis detected a change point in the data with $100 \%$ confidence as shown in Table 1. However, the confidence interval is from 1993 to 1999. Therefore, the change in COD cannot be fully attributed to the diversion project. For two-year moving averages of TP, the change-point analysis detected two points of change; 1986 and 2001, as shown in Table 2. For TN, the analysis was applied to the annual data and found that there were several change points in TN variation and the last change point detected is 7 years after the onset of the project as shown in Table 3. Since there were no other major countermeasures taken since 2000, it can be stated that there is a time lag between the onset of the project and the point of being fully effective. The reason that the effect of the project on COD is secondary is because other countermeasures such as reducing nonpoint sources have been bringing down its concentration since 1995 . For TN, the time lag between the onset of the project and the point of being fully effective may be attributed to the fact that river waters entering the lake from the Tone River have a high concentration of total 
nitrogen as shown in Figure 4. TN of river water entering the lake reached $4 \mathrm{mg} / \mathrm{L}$ in 2005 . On the other hand, TP of lake water before the diversion was around $0.4 \mathrm{mg} / \mathrm{L}$ and TP of river water entering the lake was in the range of 0.09 to $0.12 \mathrm{mg} / \mathrm{L}$ (Figure 4), much lower than that of lake water. Therefore, it can be pointed out that the diversion project is more effective in reducing TP than TN and COD due partially to the difference in concentration of each water quality parameter between the river and lake waters. Such a difference in effectiveness with regard to different water quality aspects is worth further indepth study.

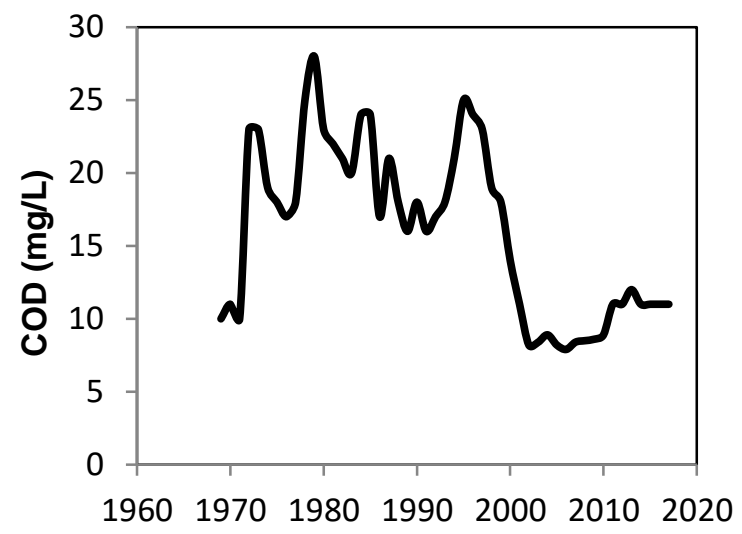

Figure 2. Annual variation of chemical oxygen demand. (Source: Chiba Prefectural Government)

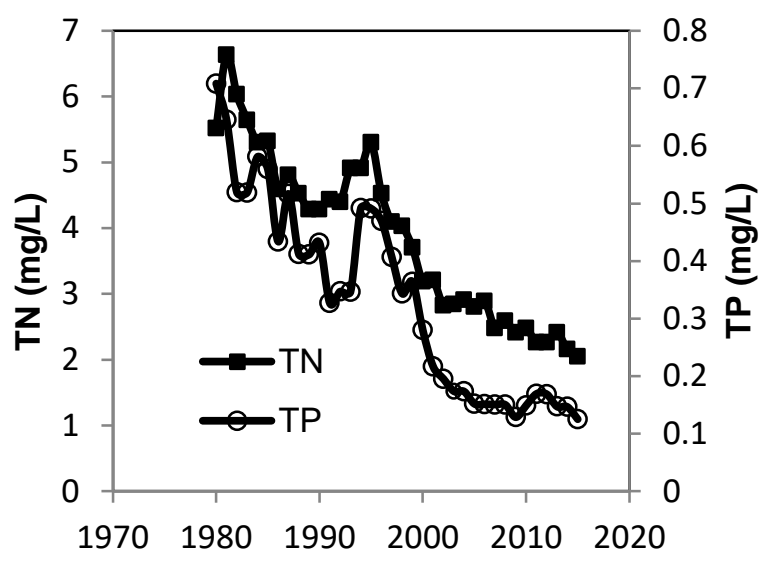

Figure 3. Annual variations of total phosphorous and total nitrogen. (Source: Chiba Prefectural Government)

In freshwater ecosystems, phytoplankton includes seven common divisions according to taxonomic classification: $\mathrm{Cy}$ anophyta, Chlorophyta, Euglenophyta, Dinophyta, Cryptophyta, Chrysophyta and Bacillariophyta. The effect of water diversion on phytoplankton communities is a concern for both researchers and managers and is understood on a case-by-case basis. In Moses Lake, the water quality was improved by adding dilution water into it, however, the blue-green algae dominance persisted (Welch and Patmont, 1992). In Lake Tega, previous studies reported that the water diversion project brought about a change in dominant algal species from blue-green algae, mainly Micro- cystis aeruginosa, to diatoms, mainly Cyclotella sp. (Yamasaki et al., 2003; Tatsumoto et al., 2007).

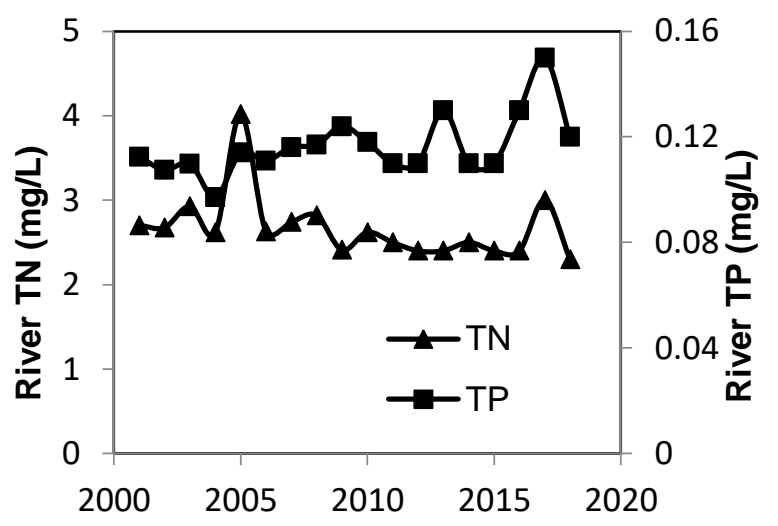

Figure 4. Total nitrogen and total phosphorous concentrations in water being diverted into the lake. (Source: Water Information System, Ministry of Land, Infrastructure, Transport and Tourism)

Table 1. Result of Change-point Analysis for COD

\begin{tabular}{lllll}
\hline Year & $\begin{array}{l}\text { Confidence } \\
\text { Interval }\end{array}$ & $\begin{array}{l}\text { Confidence } \\
\text { Interval }\end{array}$ & From & To \\
\hline 1999 & $(1993,1999)$ & $100 \%$ & 19.63 & 10.33 \\
\hline
\end{tabular}

Table 2. Result of Change-point Analysis for TP

\begin{tabular}{lllll}
\hline Year & $\begin{array}{l}\text { Confidence } \\
\text { Interval }\end{array}$ & $\begin{array}{l}\text { Confidence } \\
\text { Interval }\end{array}$ & From & To \\
\hline 1986 & $(1986,1986)$ & $91 \%$ & 0.59 & 0.4 \\
2001 & $(2001,2001)$ & $96 \%$ & 0.4 & 0.16 \\
\hline
\end{tabular}

Table 3. Result of Change-point Analysis for TN

\begin{tabular}{lllll}
\hline Year & $\begin{array}{l}\text { Confidence } \\
\text { Interval }\end{array}$ & $\begin{array}{l}\text { Confidence } \\
\text { Interval }\end{array}$ & From & To \\
\hline 1986 & $(1986,1988)$ & $99 \%$ & 5.74 & 4.6 \\
1997 & $(1992,1997)$ & $99 \%$ & 4.63 & 3.94 \\
2000 & $(2000,2000)$ & $91 \%$ & 3.94 & 2.95 \\
2007 & $(2007,2007)$ & $100 \%$ & 2.95 & 2.34 \\
\hline
\end{tabular}

In this study, phytoplankton species identification and counting for water samples taken from 6 sites in the lake during different seasons in 2018 revealed that there are 115 different Phytoplankton species in the lake belonging to three phyla; 10 species of Cyanophyta, 84 species of Bacillariophyta and 21 species of Chlorophyta. Furthermore, 11 Phytoplankton species are identified to be the dominant species in the lake. Merismopedia tenuissima, Pseudanabaena limnetica, Aulacoseira granulate, Cyclotella meneghiniana, Navicula schroeteri, Nitzschia fruticosa, Skeletonema potamos, Stauroneis anceps, Synedra ulna, Monoraphidium irregular and Scenedesmus spinosus. Therefore, the present study confirmed that this shift persisted over two decades. The disappearance of blue-green algal bloom in the lake due to the project can be considered as a significant improvement of water quality. However, we ad- 
Table 4. Biological Indexed Standards for Evaluation of Eutrophication

\begin{tabular}{|c|c|c|c|c|c|c|c|}
\hline \multirow[t]{2}{*}{ Evaluation Index } & \multicolumn{7}{|c|}{ Evaluation Criterion } \\
\hline & $\mathrm{I}$ & II & III & IV & $\mathrm{V}$ & VI & VII \\
\hline Community Structure & \multicolumn{2}{|c|}{$\begin{array}{l}\text { Cyanophyta, Chlorophyta, } \\
\text { Bacillariophyta, Euglena }\end{array}$} & \multicolumn{3}{|c|}{$\begin{array}{l}\text { Cyanophyta, Chlorophyta, } \\
\text { Bacillariophyta, Cosmarium }\end{array}$} & \multicolumn{2}{|c|}{$\begin{array}{l}\text { Dinoflagellate, Chrysophyceae, } \\
\text { Bacillariophyta }\end{array}$} \\
\hline Richness Index (d) & $0 \sim 1$ & $1 \sim 2$ & & $2 \sim$ & $4 \sim 6$ & & $>6$ \\
\hline Diversity Index (H) & $0 \sim 1$ & & $1 \sim$ & & & $>3$ & \\
\hline Evenness Index & $0 \sim 0.3$ & & 0.3 & & & $>0.5$ & \\
\hline
\end{tabular}

* I: Hyper-eutrophication; II: Eutrophication; III: The water quality is between Eutrophication and Mesotrophication; IV: Mesotrophication; V: The water quality is between Mesotrophication and Olipotrophication; VI: Olipotrophication; VII: Clean

dressed a further question "does this shift lead to true recovery of the ecosystem in the lake?".

By utilizing findings of previous studies (Kuang et al., 2005; Feng et al., 2011; Nooruddin et al., 2016), a table (Table 4) was compiled to summarize the criteria that can be used for evaluating the eutrophic state of a lake based on phytoplankton community structure and biodiversity.

For each season, dominant phytoplankton species were counted for the calculation of diversity indices. The temporal-spatial variation of diversity index was then compared with Table 4 to assess the effectiveness of the diversion project.

Figure 5 shows the spatial and seasonal change of Shannon-Wiener Diversity Index for the phytoplankton community in the lake. It can be seen clearly that the index peaked near the inlet of the diversion channel in both seasons and the values at all surveyed locations were much lower than 3 . This indicates that although the diversion project led to the shift in phytoplankton community structure from blue-green algae-dominated to diatom-dominated, the lake is still in a highly eutrophic state and the improvement in phytoplankton biodiversity by the project is limited in space. Besides which, although this shift to the diatom-dominated algae community eliminated the odor problem, it did not improve the light condition in the lake. Our measurement at the central location of the lake in autumn 2017, 2018 and 2019 showed that the SD depths were as low as 0.23 , 0.3 and $0.22 \mathrm{~m}$, respectively, which is close to the levels seen in the 1970s. Figure 6 shows the variation of annual average SD depth over the period of $1998 \sim 2015$, measured at the central area of the lake by Chiba Prefectural Government. It appeared that the water diversion project did not improve the transparency of the lake.

In Lake Tega, there were 22 species of submerged plants in the 1960s. All of them disappeared by 1973 (Yasuda et al., 1993) and the restoration of them up to now has had little success. The low light condition underwater can be considered as a main cause affecting the restoration. Based on the information mentioned above, an overall picture of what has occurred in the lake with the operation of the water diversion can be drawn as follows. The water diversion project reduced the retention time of the lake from 13 to 8 days. Since the generation time of blue-green algae, which is defined as the time for the algal population to double in cell numbers, is in the range of 30 to 50 hours, a large portion of blue-green algae would have no time to grow in the lake before they are flushed out of the lake. On the other hand, diatoms have a much short generation time so that the growth of diatoms was not negatively affected by the diversion. As a result, the phytoplankton community structure shifted from blue-green algae-dominated to diatom-dominated. Diatoms are large in size and the diversioninduced flow may have reduced sedimentation in the lake so that the presence of diatom in water may have blocked sunlight from reaching the lake-bed. The low light condition underwater can be considered as the cause of failure in restoring the submerged vegetation community.

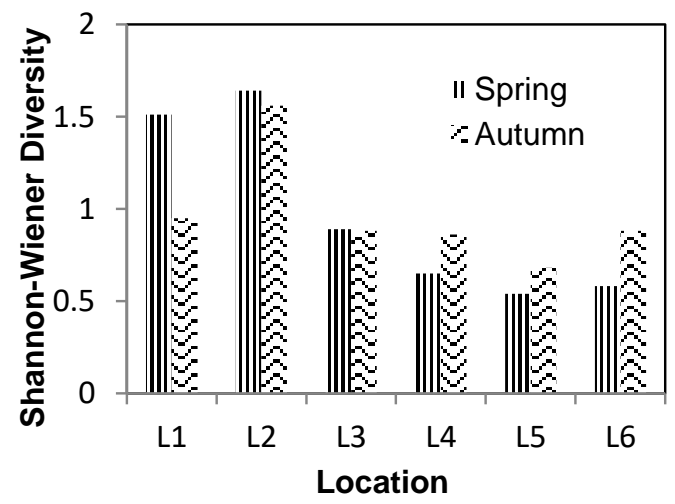

Figure 5. Spatial and seasonal variation of phytoplankton biodiversity index.

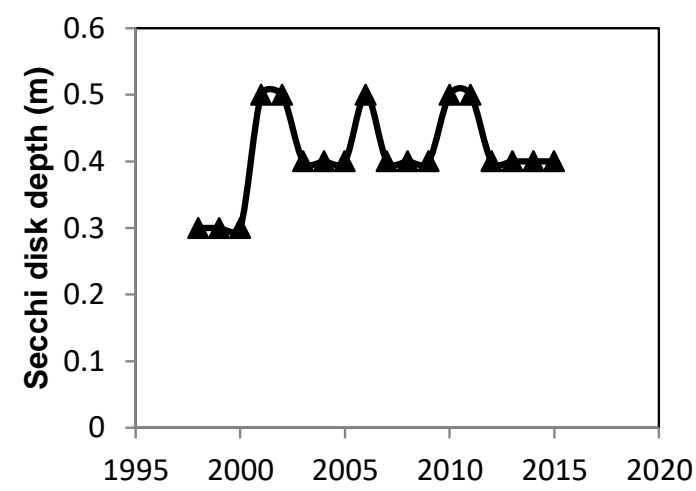

Figure 6. Decadal variation of Secchi disk depth. (Source: Chiba Prefectural Government)

For E. coli, a spatial variation pattern was found from all measured data. E. coli was highest upstream of the diversion chan- 
nel, not detected near the inlet of the water diversion facility and at the immediate downstream, then gradually increased with distance from the inlet. The high $E$. coli level in the upstream of the inlet is due to inflow from the Ohori River. The spatial pattern of E. coli implies that the water diversion from the Tone River can eliminate $E$. coli but the effect is limited to the area around the inlet.

\section{Conclusion}

Diverting water from one water body to another is a fairly widely used water management approach. The present study evaluated a water diversion project in Japan from both chemical and biological perspectives. The assessment with chemical parameters showed that nutrients in the lake have been decreased by the dilution water although the response of different nutrients to diversion may be different. The biological assessment showed that although the diversion project led to a shift in phytoplankton community structure from being blue-green algae dominated to diatom dominated, the eutrophic level remains high and the diatom-dominated phytoplankton community structure has kept the transparency of the lake low, which is considered as the mechanism that has been hindering the recovery of the submerged vegetation community in the lake. Based on these findings, the direction for further improvement work should be the further reduction of nutrients, especially nitrogen loading from the water being diverted into the lake. Such a reduction of nitrogen loading may suppress excessive diatom growth and consequently improve the water transparency of the lake. With improved underwater light conditions, there is a much better chance for the submerged vegetation community to come back, leading to a true restoration of the lake ecosystem.

Acknowledgement. This work was conducted as part of Sophia Research Branding Project funded by the Ministry of Education, Culture, Sports, Science and Technology, Japan.

\section{References}

Ahiablame, L.M., Engel, B.A., and Chaubey, I. (2012). Effectiveness of Low Impact Development Practices: Literature Review and Suggestions for Future Research, Water, Air, \& Soil Pollution, 223, 4253-4273. https://doi.org/10.1007/s11270-012-1189-2.

Angelopoulos, N.V., Cowx I.G., and Buijse, A.D. (2017). Integrated planning framework for successful river restoration projects: Upscaling lessons learnt from European case studies, Environmental Science \& Policy, 76, 12-22. https://doi.org/10.10 16/j.envsci.2017.06.005.

Biswas, A.K. (2004). Integrated Water Resources Management: A Reassessment, Water International, 29(2), 248-256. https://doi.org/ $10.1080 / 02508060408691775$.

Berndtsson, J.C. (2010). Green roof performance towards management of runoff water quantity and quality: a review, Ecological Engineering, 36 (4), 351-360. https://doi.org/10.1016/j.ecoleng.20 09.12.014.

Bandurek G.R (2008). Cumulative sum charts for problem solving, BioPharm Int, 21(5), 58-67.

Berk, S. and Taki, K. (2007). Influence of nitrogen and phosphorus ratio and dilution rate for domination between Microcystis and Cyclotella in chemostat system, Proc. of Int. Conf. Emerg. Issues
Res. Dev., Technical Session XI "Water \& Waste Water Treatment", No. 3, CD-ROM.

Collins, K.A., Lawrence, T.J., Stander, E.K., Jontos, R.J., Kaushal, S.S., Newcomer, T.A., Grimm, N.B., and Ekberg, M.L.C., (2010). Opportunities and challenges for managing nitrogen in urban stormwater: a review and synthesis, Ecological Engineering, 36 (11), 1507-1519. https://doi.org/10.1016/j.ecoleng.2010.03.015.

Change, M., Tian, X., and Li, D. (2012). Shenzhen, People's Republic of China Chapter VIII, in Good Practices in Urban Water Management, Asian Development Bank, 225-264.

Cosgrove, W.J. and Loucks, D.P. (2015). Water management: Current and future challenges and research directions, Water Resource Research, 51, 4823-4839. https://doi.org/10.1002/2014WR016869.

Dietz, M.E. (2007). Low impact development practices: a review of current research and recommendations for future directions, Water, Air, \& Soil Pollution, 186 (1-4), 351-363. https://doi.org/10.1007/s 11270-007-9484-z.

Feng, T. and Song, C. (2011). Environmental indication function of aquatic algae, Chinese Agricultural Science Bulletin, 27 (32), 257265.

Gökçe, D. (2016). Algae as an Indicator of Water Quality, AlgaeOrganisms for Imminent Biotechnology, in Thajuddin, N., and D. Dhanasekaran(Eds.), InTech, 81-101. https://doi.org/10.5772/62916

Huang, G.W. (2011). Long-term impact of policy mismatch on watershed health, International Journal of River Basin Management, 9(1), 79-84. https://doi.org/10.1080/15715124.2011.559909.

Huang, G.W. (2015). From Water-Constrained to Water-Driven Sustainable Development-A Case of Water Policy Impact Evaluation, Sustainability, 7, 8950-8964. https://doi.org/10.3390/su 7078950.

Hu, L.M., Hu, W P., Zhai, S.H., and Wu, H.Y. (2010). Effects on water quality following water transfer in Lake Taihu, China, Ecological Engineering, 36 (4), 471-481. https://doi.org/10.1016/j.ecoleng.20 09.11.016.

Iwayama, A., Hirama, Y., and Ogura, H. (2012). Long term change of phytoplankton in Lake Tega (1), Annual Report of Chiba Environmental Research Center.

Jha, A.K., Bloch, R., and Lamond, J. (2012). Cities and Flooding: A Guide to Integrated Urban Flood Risk Management for the 21st Century, World Bank Publications. https://doi.org/10.1596/978-08213-8866-2.

Komlos, J. and Traver, R.G. (2012). Long-term orthophosphate removal in a field-scale stormwater bioinfiltration rain garden, Journal of Environmental Engineering, 138 (10), 991-998. https:// doi.org/10.1061/(ASCE)EE.1943-7870.0000566.

Kuang, Q., Ma, P., and Hu, Z. (2005). Study on the evaluation and treatment of lake eutrophication by means of algae biology, Journal of Safety and Environment, 2, 87-91.

LeFevre, G.H., Paus, K.H., Natarajan, P., Gulliver, J.S., Novak, P.J., and Hozalski, R.M. (2014). Review of dissolved pollutants in urban storm water and their removal and fate in bioretention cells, Journal of Environmental Engineering, 141 (1), 1-23. https://doi.org/10. 1061/(ASCE)EE.1943-7870.0000876.

Liu, J., Sample, D.J., Bell, C., and Guan, Y. (2014). Review and research needs of bioretention used for the treatment of urban stormwater, Water, 6 (4), 1069-1099. https://doi.org/10.3390/w60 41069 .

Mays, L.W. (2007). Water Resources Sustainability, McGraw-Hill Education, New York, NY, USA.

Motohashi, K. (1986). Phosphate release from bottom sediments and dissolved oxygen, Japan Journal of Water Pollution Research, 9 (1), 45-48. https://doi.org/10.2965/jswe1978.9.45.

Matsunashi, S., Inoba, S., Shimongaki, H., and Miyanaga Y. (1999). Analysis of seasonal and spatial characteristics of water quality in Lake Teganuma, Proceedings of Hydraulic Engineering, 43, 9951000, 1999.https://doi.org/10.2208/prohe.43.995. 
Morrison, A., Westbrook, C.J., and Noble, B.F. (2018). A review of the flood risk management governance and resilience literature, Journal of Flood Risk Management, 11, 91-304. https://doi.org/10.1111/ jfr3.12315.

Rathnayaka, K., Malano, H., and Arora, M. (2016). Assessment of Sustainability of Urban Water Supply and Demand Management Options: A Comprehensive Approach, Water, 8, 595. https://doi. org/10.3390/w8120595.

Schmutz, S., Kremser, H., Melcher, A., Jungwirth, M., Muhar, S., Waidbacher, H., and Zauner, G. (2014). Ecological effects of rehabilitation measures at theAustrian Danube: a meta-analysis of fish assemblages, Hydrobiologia, 729, 49-60. https://doi.org/10.10 07/s10750-013-1511-z.

Tatsumoto, H., Amano, Y., Sakai, Y., Machida, M., Aikawa, M., Fujimura, Y., George, D., and Taylor, W.A. (2000). Change-point analysis: a powerful new tool for detecting changes, https://www. variation.com/cpa/tech/changepoint.html.

Tabuchi, T. (2008). Pollutant Load of Nitrogen and Phosphorus into the Lake Modified by the Concept of Background Load, Trans. of JSIDRE, No.257, 65-70. (In Japanese)

Uusi-Kämppä, J. and Jauhiainen, L. (2010). Long-term monitoring of buffer zone efficiency under different cultivation techniques in boreal conditions, Agriculture Ecosystems \& Environment, 137 (1), 75-85. https://doi.org/10.1016/j.agee.2010.01.002.

Vojinovic, Z, and Abbott, M.B. (2012). Flood Risk and Social Justice: From Quantitative to Qualitative Flood Risk Assessment and Mitigation, IWA Publishing. https://doi.org/10.2166/97817804008 22.

UN (2018). The United Nations World Water Development Report, www.unwater.org/publications/world-water-development-report2018/, Accessed 20 Feb 2020.

WHO (2001). World Water Day Report - Water for health: Taking charge.https://www.who.int/water_sanitation_health/publications/ water-for-health-taking-charge/en/, Accessed $20 \mathrm{Feb} 2020$.

Welch, E.B. and Patmont, C.R. (1980). Lake restoration by dilution Moses Lake, Washington, Water Research, 14 (9), 1317-1325. https://doi.org/10.1016/0043-1354(80)90192-X.

Welch, E.B., Barbiero, R.P., Bouchard, D. and Jones, C.A. (1992). Lake trophic state change and constant algal composition following dilution and diversion, Ecological Engineering, 1(3), 173-197. https://doi.org/10.1016/0925-8574(92)90001-I.

Walmsley, N. and Pearce, G. (2010). Towards sustainable water resources management: bringing the Strategic Approach up-to-date, Irrigation \& Drainage Systems, 24, 191-203. https://doi.org/10.10 07/s10795-010-9100-z.

Yang, Y., Yin, X.N., and Yang, Z.F. (2016). Environmental flow management strategies based on the integration of water quantity and quality, a case study of the Baiyangdian Wetland, China, Ecological Engineering, 96, 150-161. https://doi.org/10.1016/j.eco leng.2015.12.018

Yamasaki, Y., Nihei, Y., Inotsume, T., and Nishimura, T. (2003). Influences of discharge variation of purification water on water quality environments in Lake Teganuma, Proc. Riv. Engine., JSCE, 9, 505-510. (In Japanese)

Yamada, Y., Tachimoto, E., and Shiratori, K. (1993). Lake Inba Lake Tega-Proposal for their Water Environment, Kokonshoin Publisher. (In Japanese) 